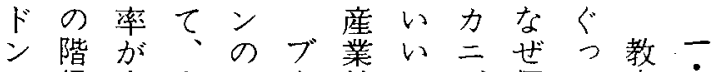

の級高上モ| 社か ズ個て育亡 -

仮にり市卡会之厶八多に

定入。階ルンのれを的〈はブ

手吕ま級はは理ば考行の社ば

続はどう機的会しの究会シ機

老学経学の会毛移、集加移毛会

順歴済力部会方動 1 合行動

にの的が分不儿は 1 方的のル不

追み要高か平を增教シれ千の平

つで因いら等構大育页てヤ構

て決に。なを築手機テきき造

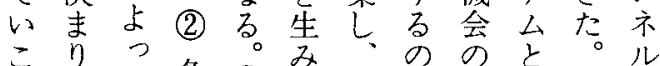

うりて各 (1) だそか不しブル

ブ出同踏階要に?、平て、等階・゙た

!階学学級基と級之社

ド級学力占方い縮のつ会

二に力の光しいう再五的

のよで組学て て 2 方生导地

分方市合力学文了方産言位

析なっせの文ミのの艺継

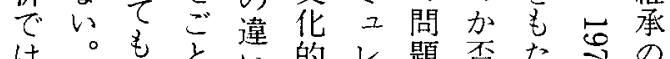

は。高々高学的レ題否た氙の

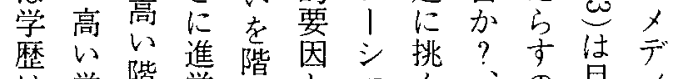

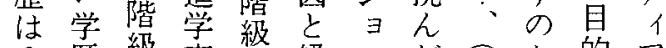

9 歴級率別経之だ 2 か的ア

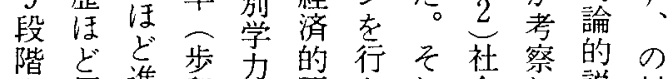
あ優售留分要なし会し説対

先学率布因气盾的た明立

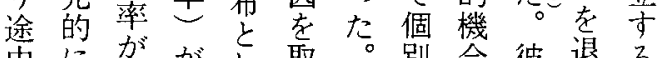
中にががし取。別会彼退る で高高異てりのののはけ2 6 い。な与社不機てつ

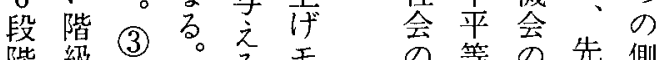
階級 (3)。る 会等 の 先側 にに教学る。デデは不進面 ま配育力文儿|縮平産が と分をが化化多小等業あ

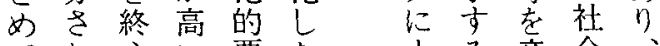

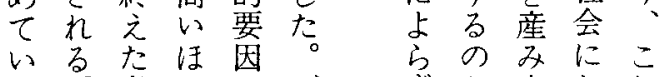

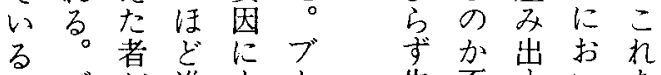

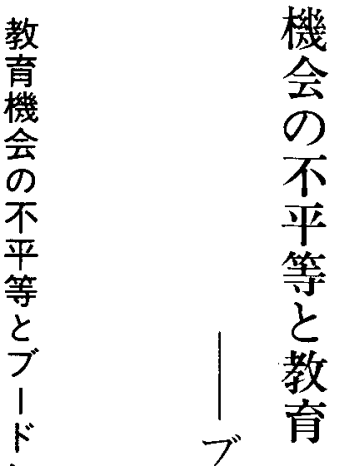

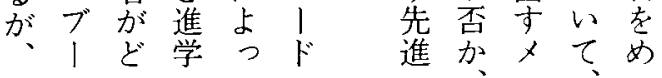

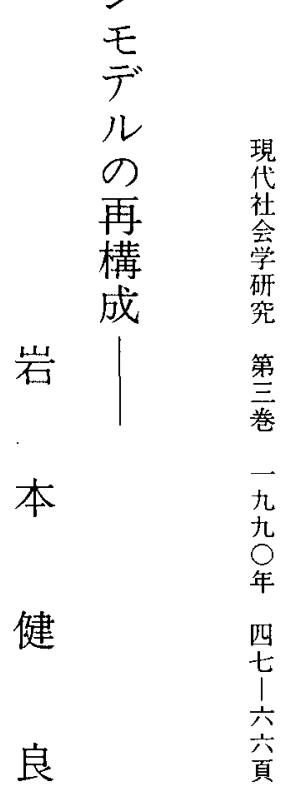


次る。段 学

よこを般段の進

㞦最化階 2 学階で階 的にら終しまつ率級与級 $\times し か$ 学てでのの别え間 品求 、歴進表分学名学

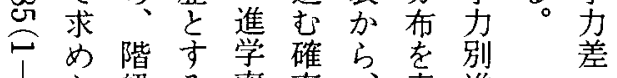
ら級る率率、表進

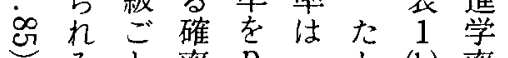
+ 。

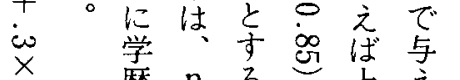

× 歴 n る 尚 分尔と、!流る。

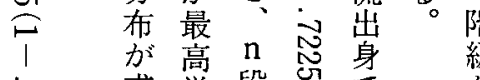

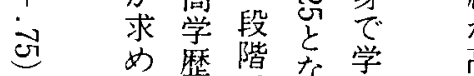

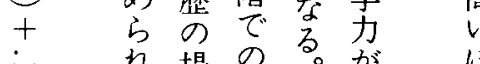

的場

宛合学

Ð たは率

啗 代

II

親

文

的

響

に

$\tau$

階

級
が
高

传
上

生 ()

准

$\begin{array}{ccc}\text { 上 } & \text { n } \\ \text { 流 } & \text { 段 } \\ \text { 階 } & \text { 階 } \\ \text { 級 } & \text { ま } \\ \text { 出場 } & \text { 進 } \\ \text { 身 } & \text { 合 } \\ \text { 学 }\end{array}$

的学

ちはる

学罗確

歴方率

苟骂

๖

人 1 な

此 1 。

率 ま

はをな

\section{率}

は 力 少 生

- 高

八 以

五

あ

る。

ま
の
生
徒

が

占

上
力

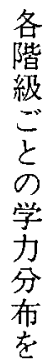

高各階

以。級

各皆立

級学

学分

力市索
進

ぞ
生
墕
学
力
は
高
い

ど
生
徙
学
力
は
高
い
。

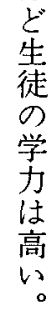

ど
生
徙
学
力
は
高
い
。

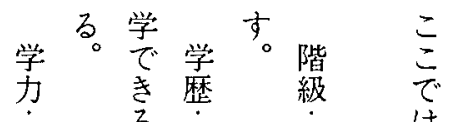

3 る

人 3

$\begin{array}{ll}\text { の } & \text { 割 } \\ \text { 段 }\end{array}$

階階

がー 一が

あ 定 あ

市。
割。

上 合 具

$\mathrm{p}$ 体

ら に的

順限に

に らは

れた

$R_{1}$ 当

$\mathrm{R}_{2}$ 残 ば

$\mathrm{R}_{3}$

) 中

之

の) 学

は

そ 高

時

点 $\mathrm{E}$

社奋 6

会 $E_{3}$ 人

出劣

出考

以 之 が

後它的

学毛方。

校

に学。片

る 12 を

は $\frac{1}{\sigma} \quad \mathrm{C}_{2}$

な 段

京進表
人 $\mathrm{E}_{1}$ 
表 1 階級間学力差と階級別学力別進学率

\begin{tabular}{|c|cccc|ccc|}
\hline \multirow{2}{*}{ 階 級 } & \multicolumn{3}{|c|}{ (a) } & \multicolumn{3}{|c|}{ 階級間学力差 } & \multicolumn{4}{|c|}{ (b) 階級別学力別進学率 } \\
& \multirow{2}{*}{$\begin{array}{l}\text { 学 } \\
\mathrm{R}_{1}\end{array}$} & $\mathrm{R}_{2}$ & $\mathrm{R}_{3}$ & 計 & $\mathrm{R}_{1}$ & $\mathrm{R}_{2}$ & $\mathrm{R}_{3}$ \\
\hline $\mathrm{C}_{1}$ & .6 & .3 & .1 & 1.0 & .85 & .75 & .65 \\
$\mathrm{C}_{2}$ & .5 & .3 & .2 & 1.0 & .70 & .60 & .40 \\
$\mathrm{C}_{3}$ & .3 & .4 & .3 & 1.0 & .60 & .40 & .20 \\
\hline
\end{tabular}

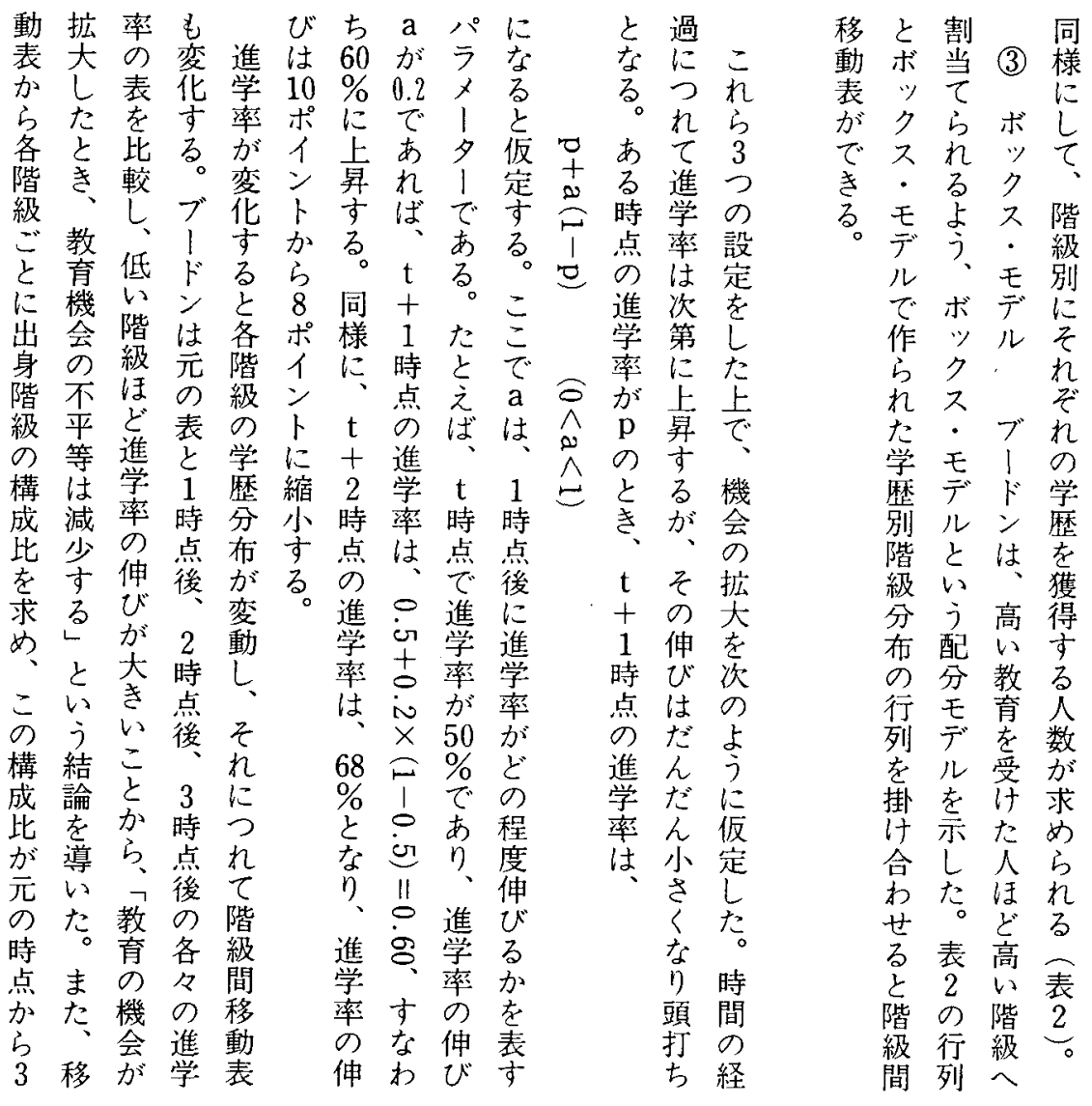




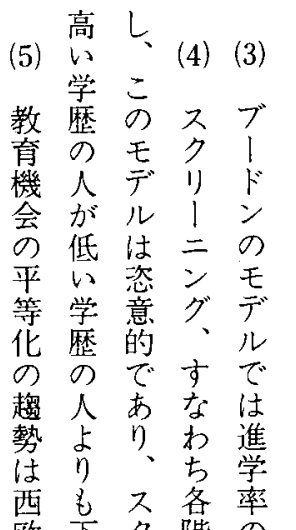

欧下ク階の

諸のリ級極

国階 | $八$ 限

の級二のは

中に吩学 1

で所 グ 卒 と

遍し基のる

的户本配

に古的分で進率

みいなを学の

ら、仮、教率伸

れと定ブ充のび

るいに1機伸の

現う反ド会びパ

象こ京ンの命う

でとるは平止 メ

はが結 ボ等つ।

な起果 $\%$ 化て夕

くき索クはい!

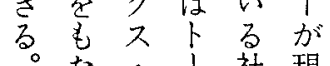

国。た。! 社現

にらモ卜会実

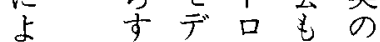

っこルジあデ

て 它で 定儿る。

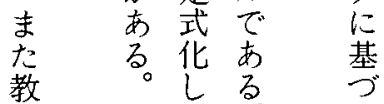

充なた。

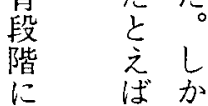

表 2 階級別学歴分布

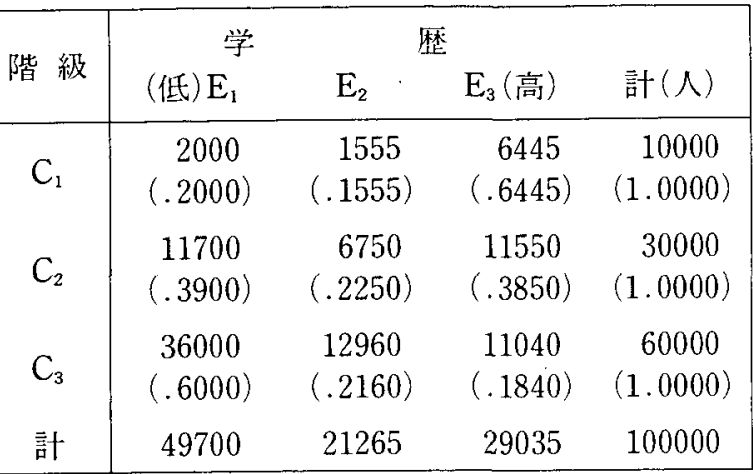

（）内は比率 


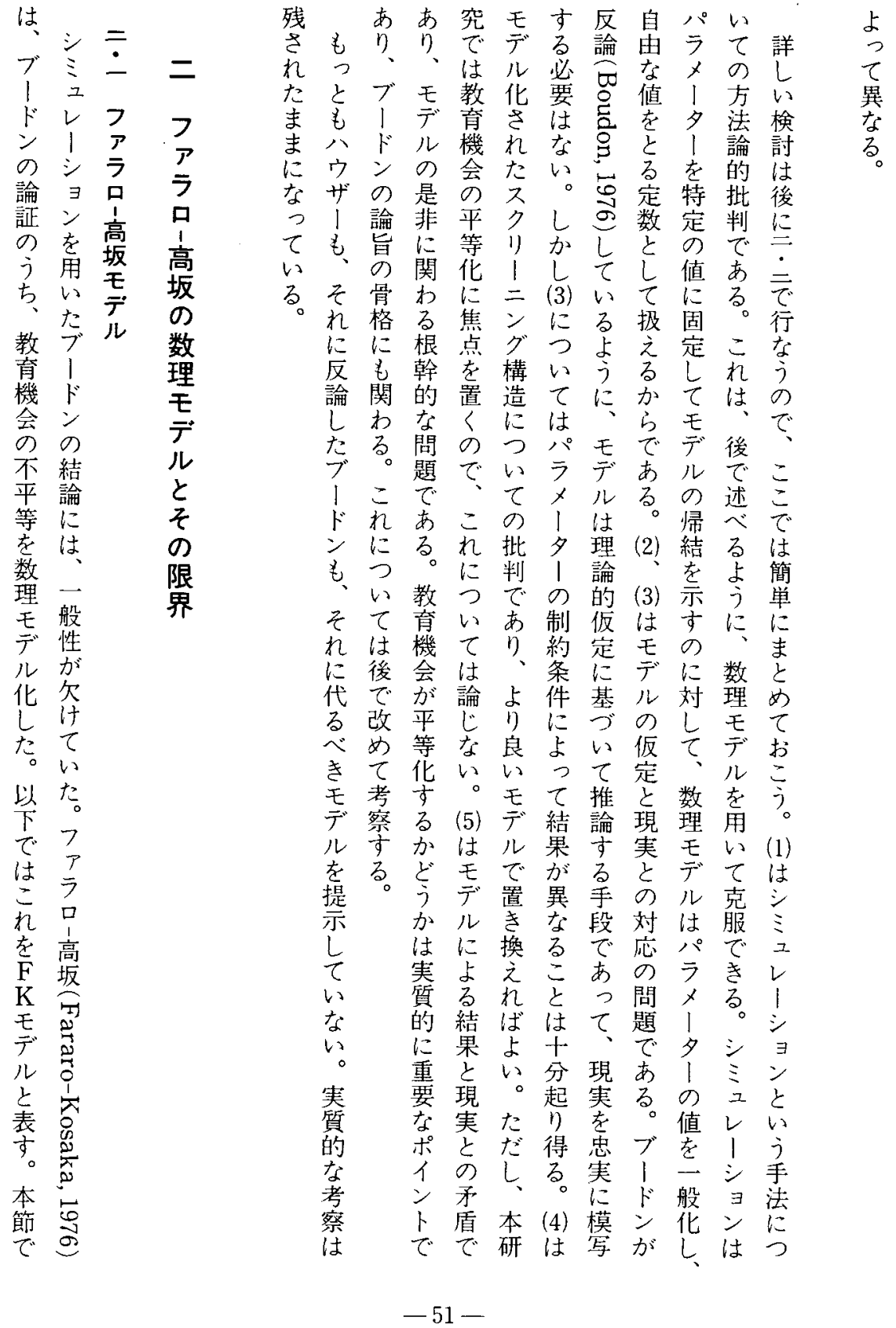




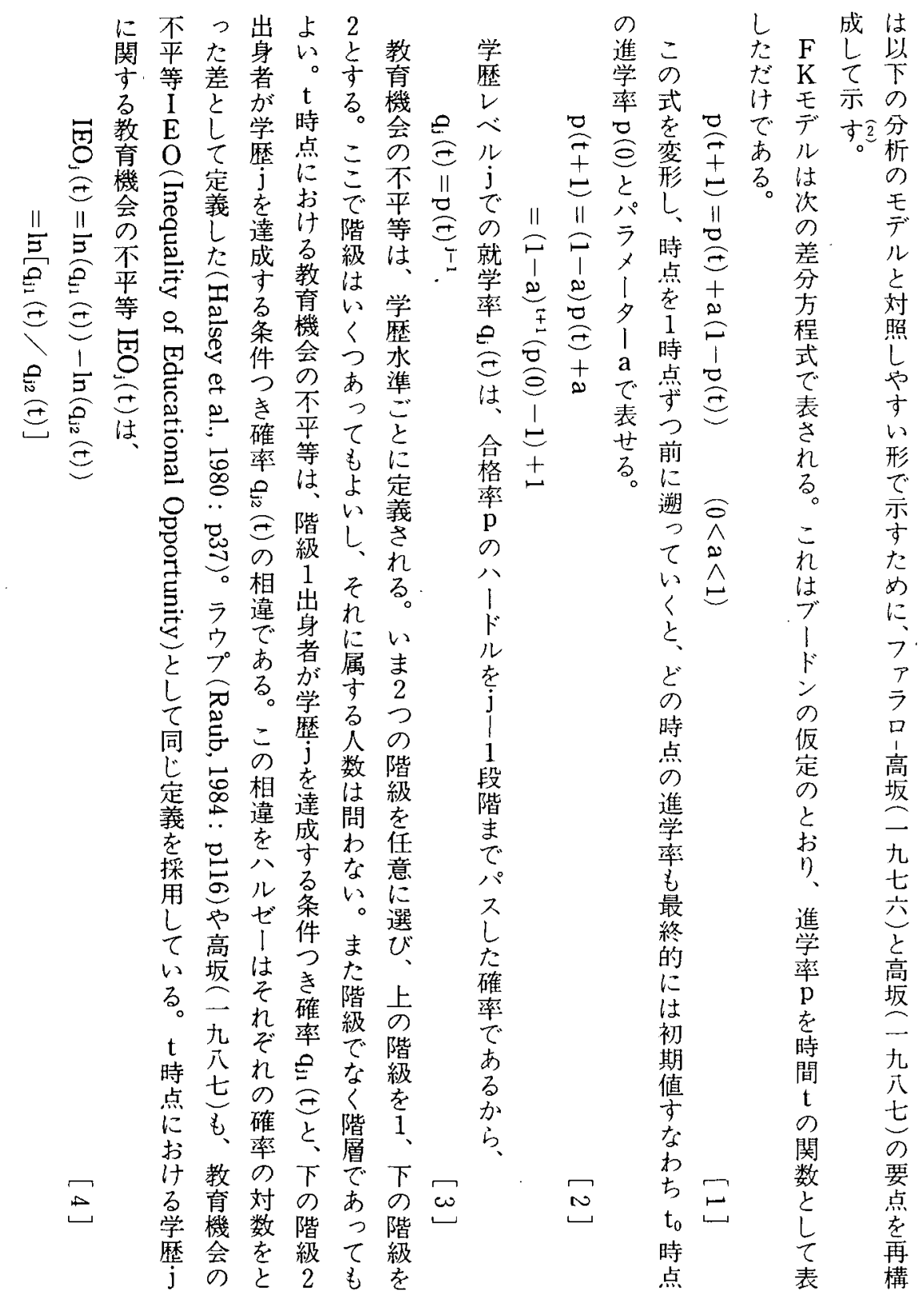




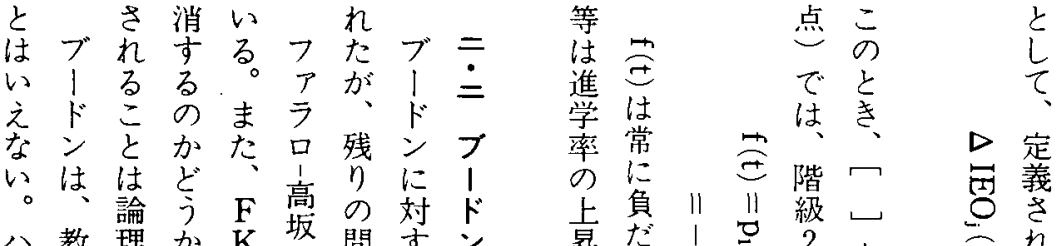

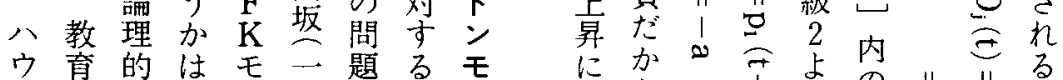

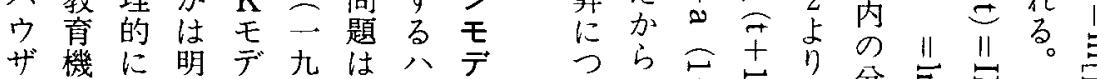

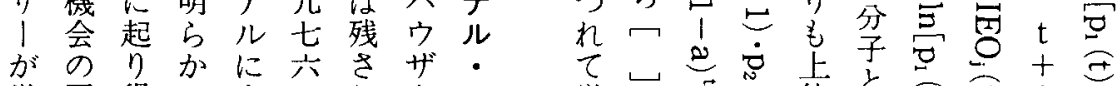

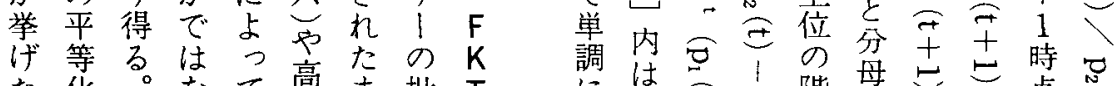

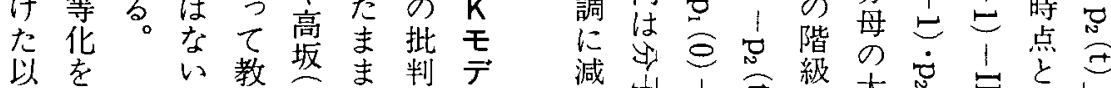

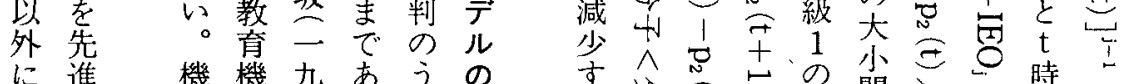

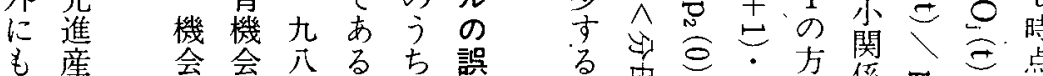

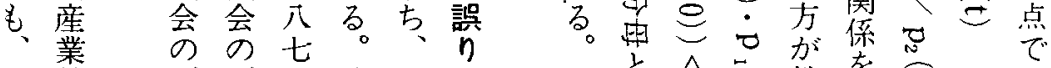

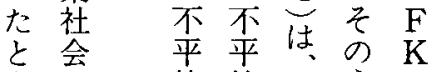

之の 等 等 ブ

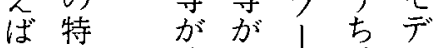

1 徵 時次㳊重儿

ギとを第ン要は

1) と追にと先

冬主方縮同 (3)

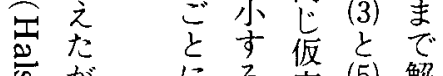

忍が、に定 (5) 解

改こ比決

它謷善文持つで

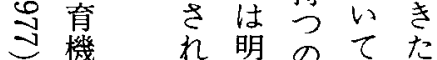

や機会明のてた

户会电かでめら

メ不、にブてう

リ平 二さ!考加

力等定れド察 (1)

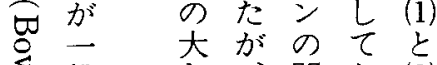

き般导、問お(2)

恋に帒題この

$\sqcup$ 縮市点う。前

毛小不がを。半

き 平完継は

でて 等全承解

教い㤎にし 決

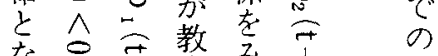

なっさ弈みさ学

$の \frown$ 機た可歴

で 0 会め主

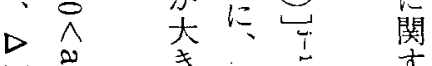

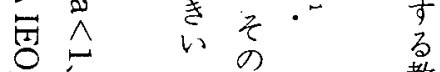

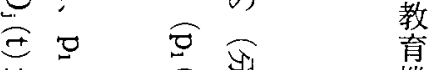

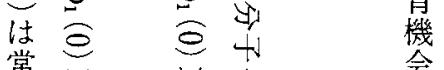

常 $v$ v

負号 总雪 不

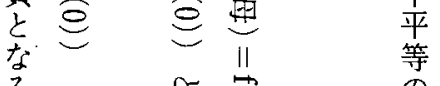

る

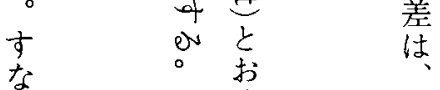

育る 残 解 て さ

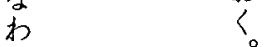

方最

教初

時 


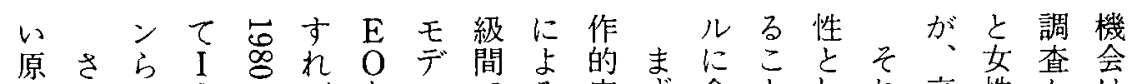

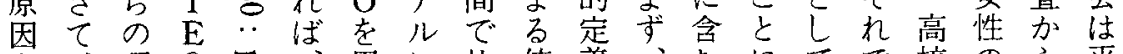
を、理 $\mathrm{O}$ 巳吕用に比值義、むにてで校のら平

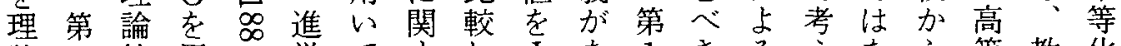

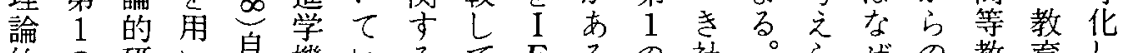
的の 研以 自機 以晕

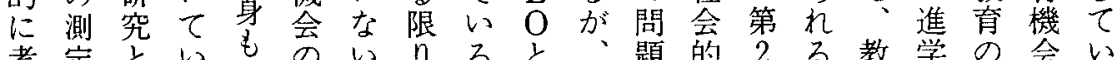

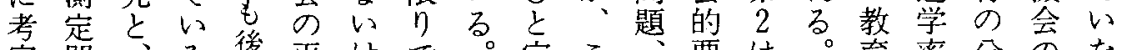
察問、る後平けで。定こ要は。育率分のな し 題この洒等れはし義こ教因理第機で野二い

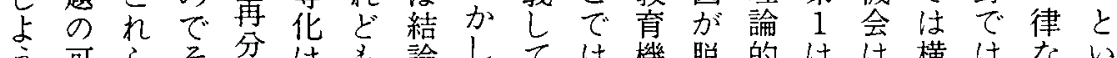

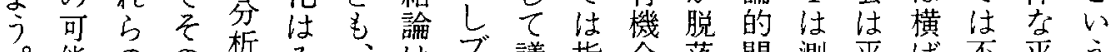
。能のの析み、はブ議指会落問测平ば不平う

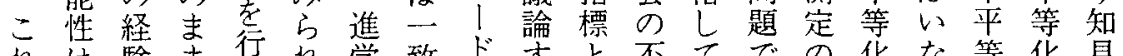

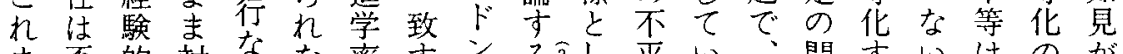

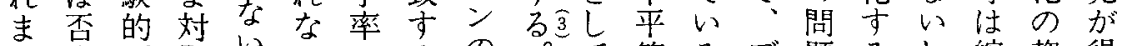

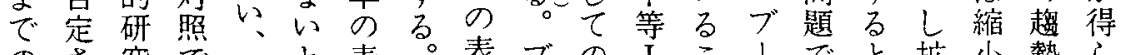
のさ究で I と表。表ブの Iこ!でと拡小势ら

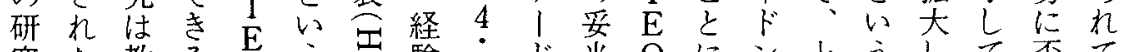
究 た 教 る らで機し 次機の゙がて結号に $\mathrm{E} I$ I に

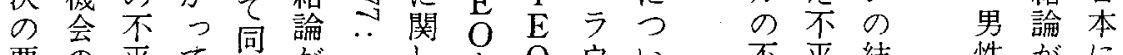

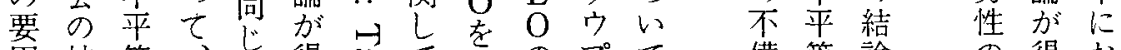

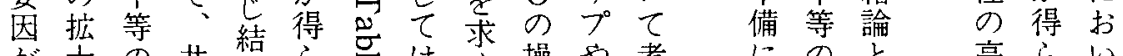

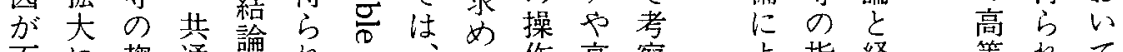

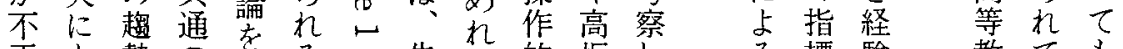
平も勢 $の$ 導る。先ば的坂し る標験教ても 等加に 指 隹 。 縮わ L I い

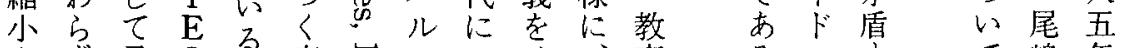

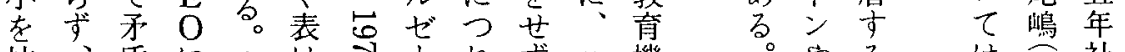

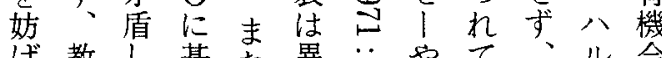
げ教し基な異 $\cdots$ やて 、儿会

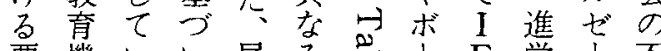

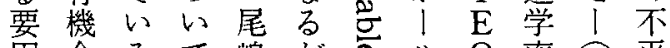
因会るて嶋が点ル $\mathrm{O}$ 率 と命こ考は、学落 し否と察不八かは減伸要に て平 がし平儿らら、少びษは 考等 確て等ゼ I 指京率范

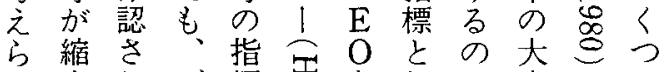
れ小れブ標焉をしで小のか るした!と齐計てそ指の

○ る

$=70$

れアだ

はうろ

口交

仮」かは社

定高。不よ会

坂次平㣗移

誤のの等ば動

や分 2 は 縮中 $\overparen{\mathrm{S}}$

や析つ 縮 中 $\mathrm{S}$

モ異可 L 教 $\mathrm{M}$

デな能た龍心 
誤平ら終ン違

$\eta$ 等 ず

れンほ\%いう

(c) るのとかたに

でで、時 分文

こ仮 んらり

(b) 少仮 今゙

ああ教で析化階と定ど 80 片進学述ブ等摘し進

るる育はで的級がは変\%方学歴べ| 教のなな学

。と機 37 は遺間不成华にの率段るド育とい率

まし会加、産学平立が伸伸の階、ンを的。頭

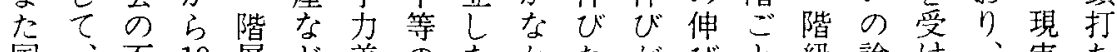
国・不 19 層ど差のなががじと級論け故、実ち 民進平に間のの二いつが時はの間証るづ的の の学等、学要効因。た、間教進学 プよ!に効 所率の高力因果に仮志高的育学力口占も果 得の主等差をなに考校にレ率差七にン各

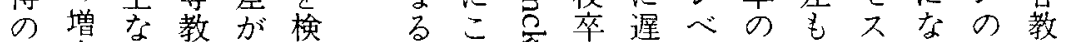
増大原育な討ブとれれ心業れル伸こがれモ育国 大に因入いしに考にに者るにびの正ば方レ民

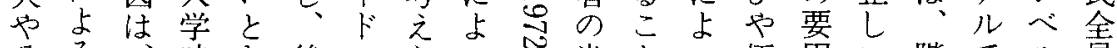
公る、時き後ンらつ 私影階で、のはれて数もて限をと級ははに の響級は上分教る教可があ、の抜し間進何高 奖の間 18 層析育。育的大るた相きて学学引等

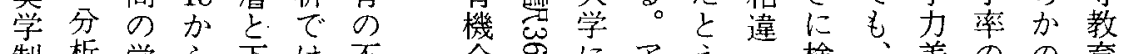
制析学ら卡は不会怘にア 度は力 10 層階平合。進 メば討そが極限を の行差への級等不古学り高又での就限界受 充なでと差間を平なし力校パき議学はをなけ 実つああ、異学生等わ、でとデな論率 1 持さ

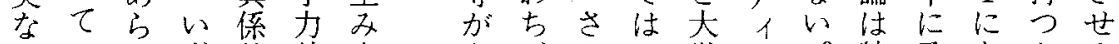
ぞいわず数差出半、ら一学|特及なとる

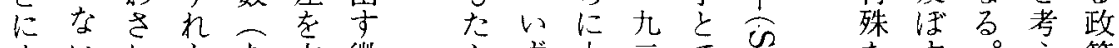

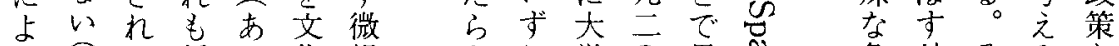

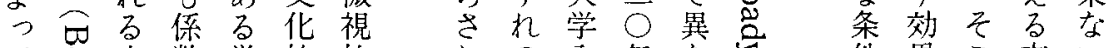
て 齐数学的的的の年な件果こ方い 経名的 值碟遺 理 済尚不方達の と 的

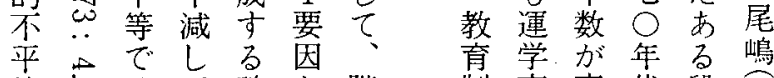
等艺はて 確と階制率卒代段二 が○尔い率し級度は業ま階九 進こくる。て間伸玄ででて 学 $の 、$ 比考 に議むそ学る 及論しれがし 価 ぼは方に、值 寸明経も高。体 効 ら済等ブ亲

果加的加教 | の はに不わ㕕ド相

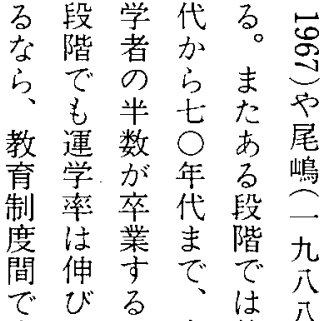
成ると高伸公 長とい校びに のいう 卒がみ 足う構業停ら 並ブ造者滞れ が!ははしる
にはでがし 基実、自目 づ質 階 然 標 く的級でを 寻に間あ持 のは学るつ で無力。政 あ意差こ府 り味がれは にあにわ 愦なつ対饥 $\eta る \tau \downarrow$

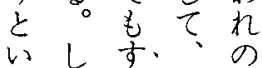
えたべ八知 るがて、ウる 
表 3 教育機会の不平等モデルの構造

\begin{tabular}{|c|c|c|c|}
\hline & ブードン & ファラロ-高坂 & 本 研 究 \\
\hline 分 析 手 法 & シミュレーション & 数理モデル & 数理モデル \\
(1) 階級別学力分布 $\quad \mathrm{C} \rightarrow \mathrm{R}$ & 固 定 & - & 自 由 \\
(2) 階級別・学力別進学率 (C, R) $\rightarrow \mathrm{E}$ & 差が縮小 & 差が縮小 & 階級間のみ縮小 \\
進学率の亟限 & 1 & 1 & $0<\mathrm{b} \leqq 1$ \\
学校段階ごとの進学率 & - - & 一 定 & 自 由 \\
\hline
\end{tabular}

を可は機 1

導能現会にブ

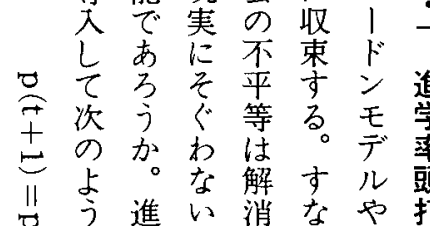

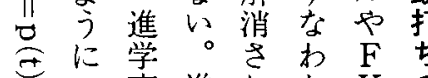

+ 二率進的 5 K

今般が学る。時气効

亏 化 b 率。間デ果

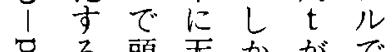

巳る。頭忝か経は

ち 效

に果す市す

ながべれべ

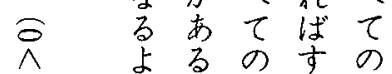

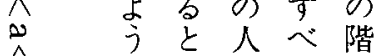

$\wedge$ 、きがて級

F に 最の.

今 $\mathrm{K}$ 王卡学

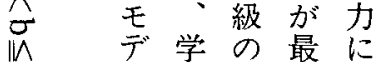

き ル 歴学上卡

にの校 級い

パ不にのて

ラ平行学

$\square \quad x$ 等

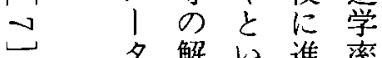

夕解 以進率

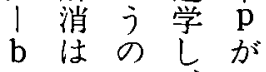

か 教理機因す縮 否育し分会でる小 か のて 析 の あ経し を不おに不る済つ 検平こ入平の的つ 証 等 うる 等 か不 あ すが。前の否平る る。縮 以に維が等し、 すの各に検縮こ る 各 モ 効 証小の の 節 デ果す かでルをるつ小 否はの持。つは か、構つ教あ理 ここ造な育る念 まれ 的 $ら$ と 的 たら特ば拡きに 絔 3 徵 7 充、导 小要 とブに文支 因先 | 老化持 れをにドか的さ る毛挙ンか不れ とデげのわ平て 子ルた愦ら等い れの 3 りずがる。 ば中要が文教。 全組の証的の稿 なみ関さ不不で 解入係㣗平平は 消れをる 等等

にた袁。がを進

至上 3 教 生 学

るき、整 充愿関 


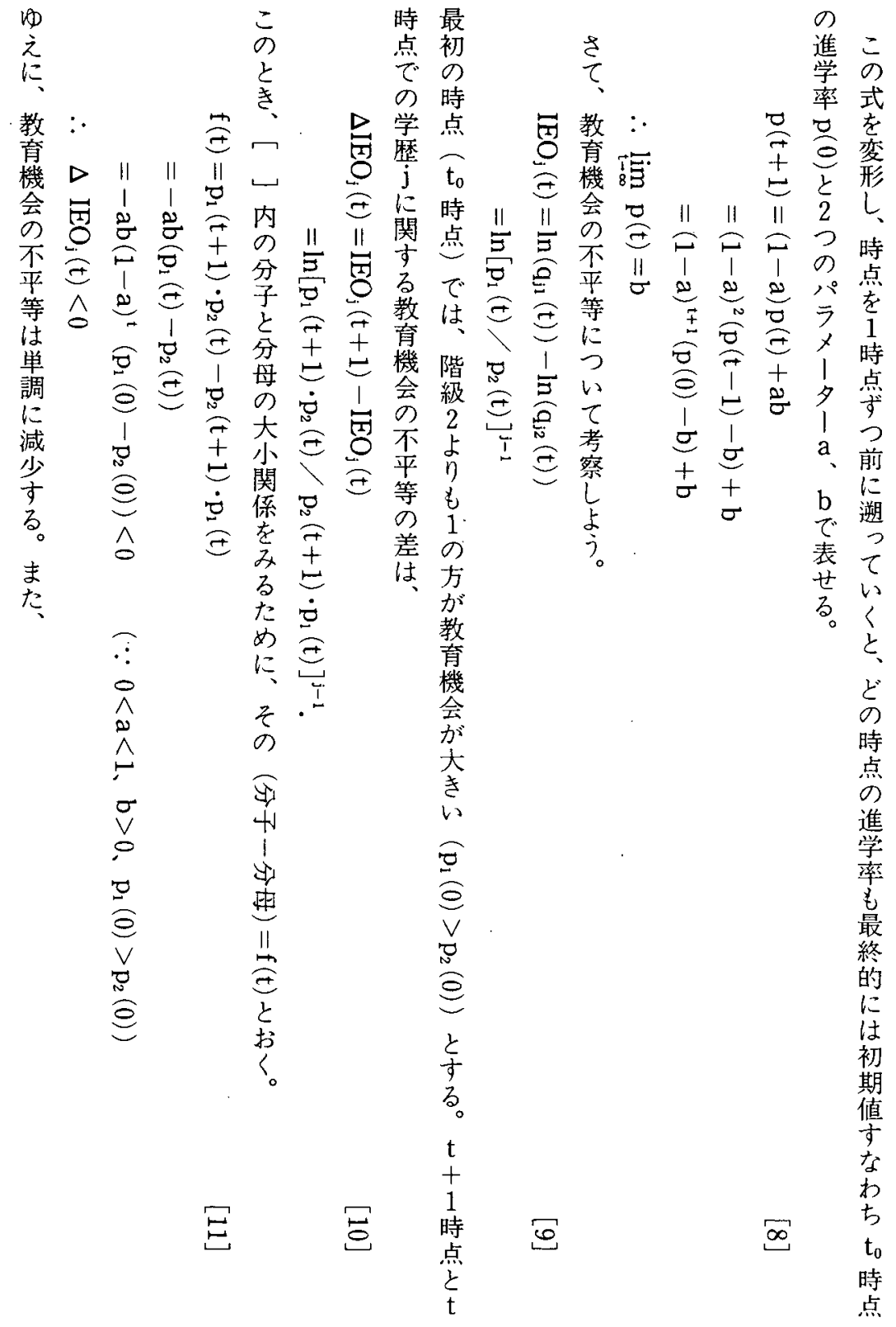




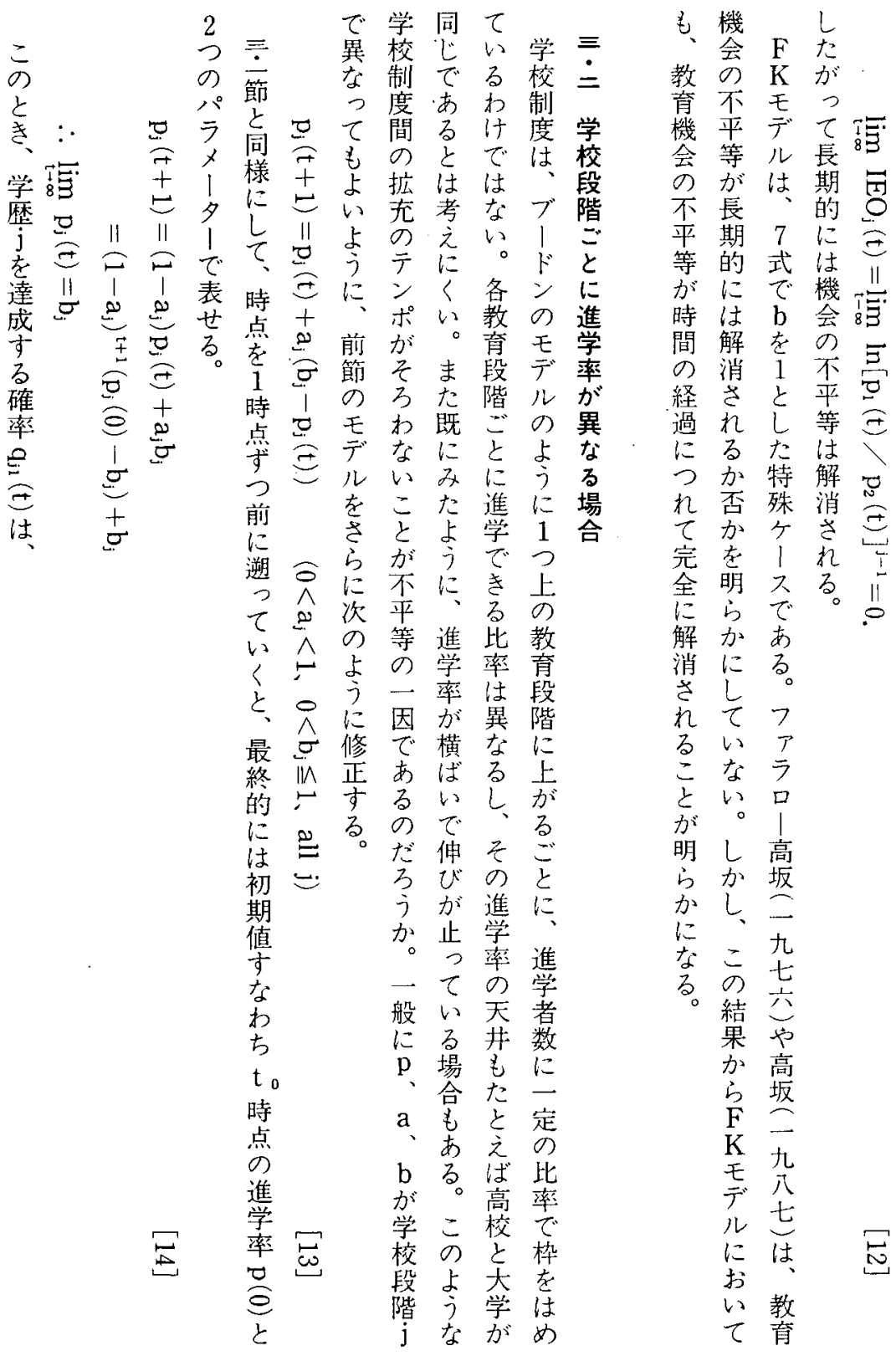




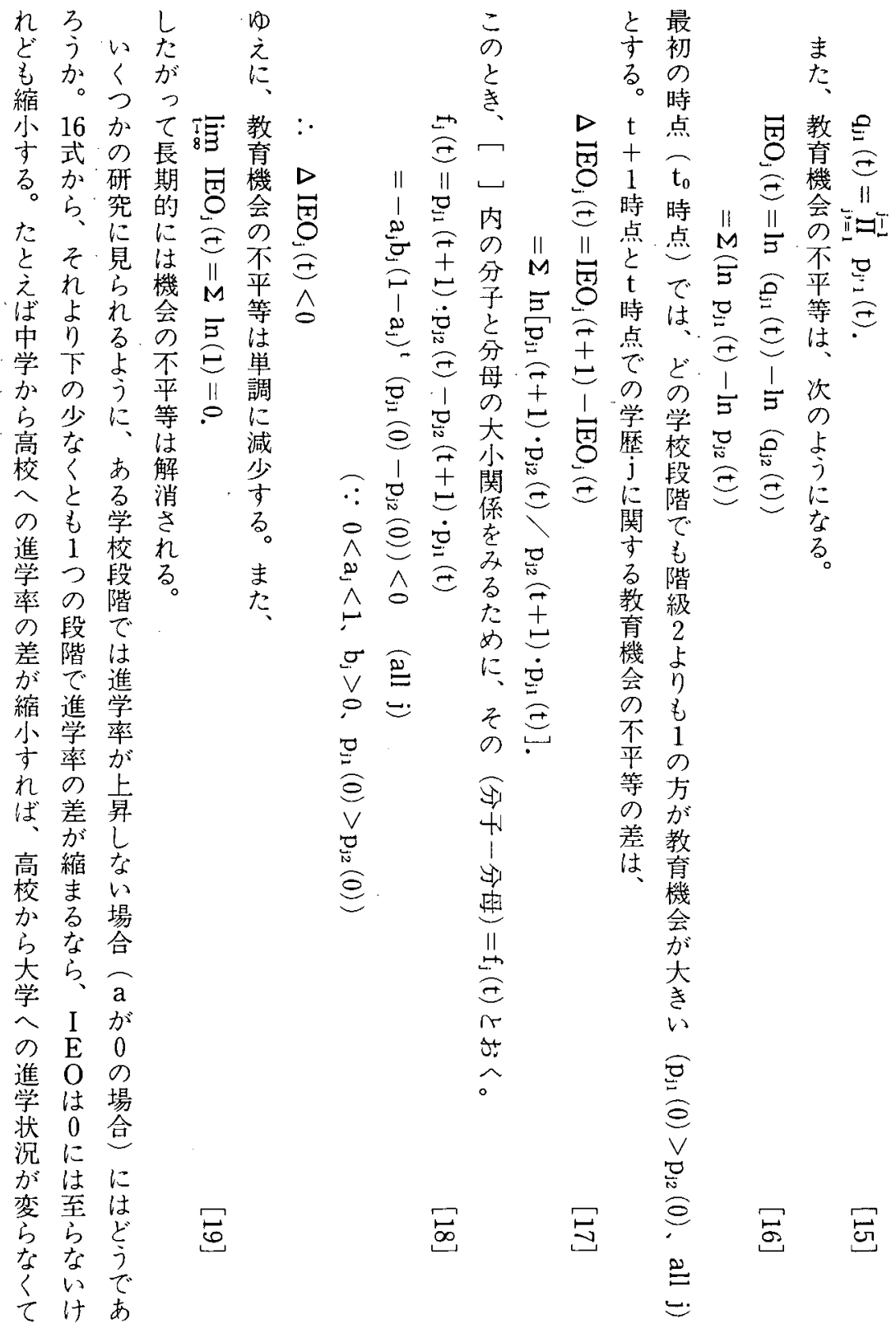




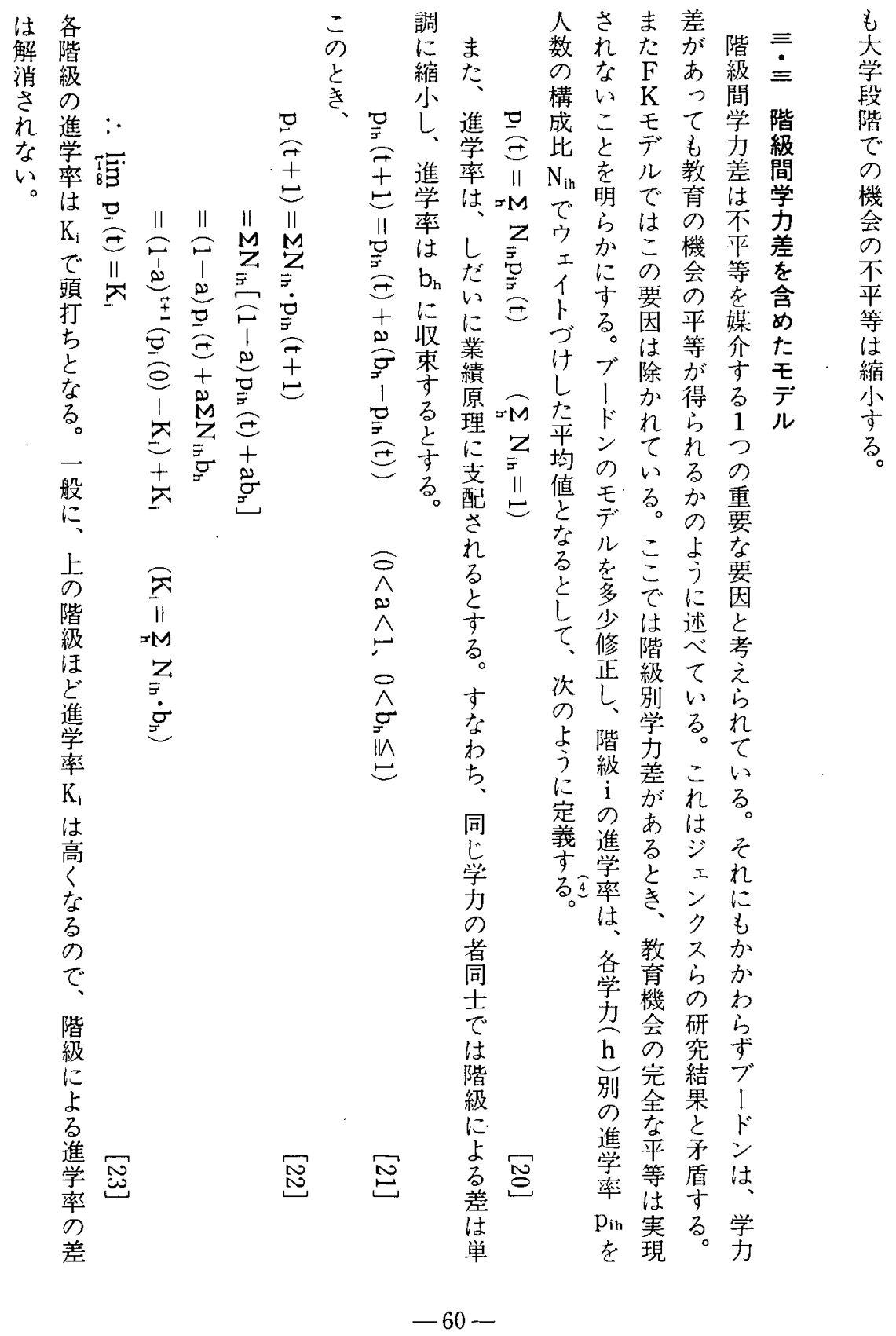




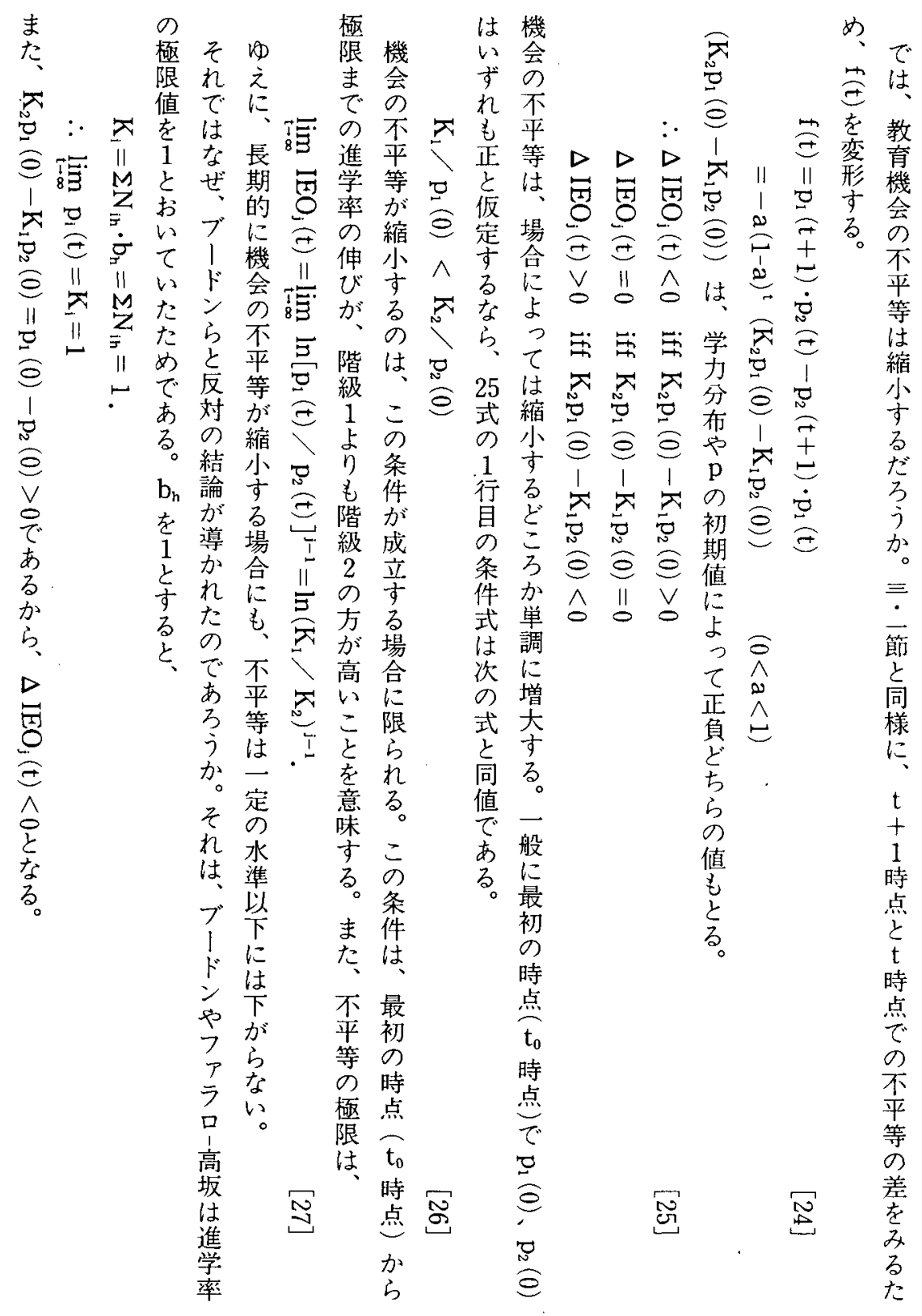




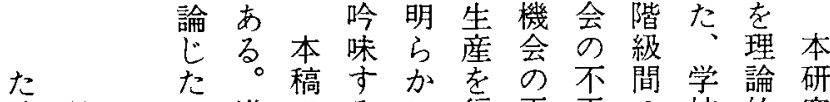
論付以進でるに行平平の校的究 文記。学は必さな等等学制にで を率要れつ化を力度考は

元 本

に稿

修标

正. 第

- 62

加回

筆 日

ᄂ 本

た社

会

の) 学

で 会

あ大

る 会

有 -

镨九

な八

助九

年

支一

頁 $\bigcirc$

以 月

た二

白日

拿東

男京

高早

坂 稲

健 田

次太学

小次

林で

㳯 報

一、告

平 配

松 布

閣 L
の進性た可てとむ格の察

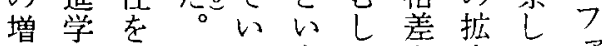

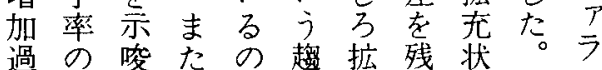

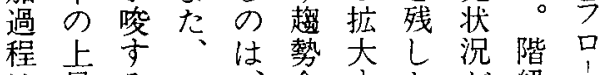

は昇るこ铪子た卉級高

階は。れ文題るま段間坂

級外ら化に。ま階にの

間坐 の的对ま業に学モ

の的㷌条した績よ力デ

相に結件て主つ差儿

互決との、不義てがを

準 定

拠已

的乐

$x$ る

力 と

天 $\frac{L}{\tau}$

厶 E

<

儿化

\& $L$

捉た

之 が

5 僬

丸進

上 学

う。率

変

自

○体

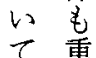

は要

な

稿 社

改 過

め程

て で
し相 济平老異な修

て異工等追ない正

ブ通ク䈹夺て求つ場し

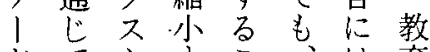

ドてらすこ、は䏍

ン教とるとこう機

に育同場はれ進会

上と様合、に学の

る選にで機よ率拡

社抜否も会つが大

会に定、のて 頭が

的内的市平機打教

不在なる等会ち育

平的結水を爷で機

等に論準も不导会

の組が以た平教の

䞨込引下ら等育不

勢まきにさが機平

にれ出はな拡会等

関たさない大のの

す 的ら文平縮

る力るな条る等小

命二。い件こがに

題 ズ教。にともつ

にム育すよはたな

つにがなつならが

い上不わているら

てる平ちは。机な

も、 こ等 教 し る。教

再 が再弆機しま丒
況

に逆

四推に

移 い

す j

るな

な ら

、階

教 級

䘚 間

機 に

会学

力

不の

平 差

等 が

はあ

次り

第 そ

にれ

縮 が

小 解

ᄂ 消

究的

極な

的 w

に上

完て

全

解 す

消 べ

¿

的

る 人

最

高

学

歴

蒿

得

で

き

状 
(5) (4)

(3)

(2)

注

レ段す明分較し比不今りなる。る る の

(1) 木

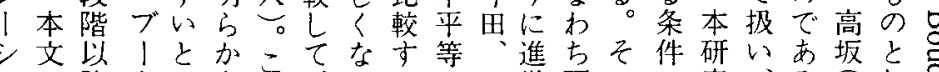

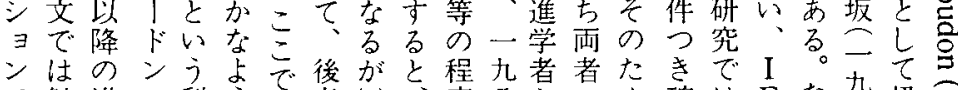

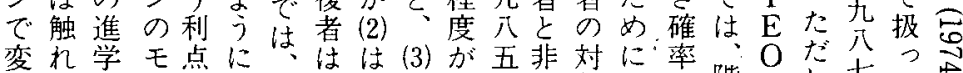

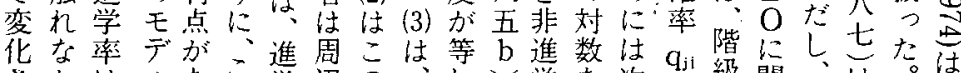

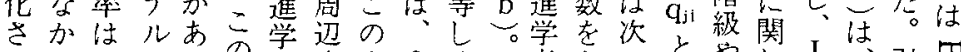

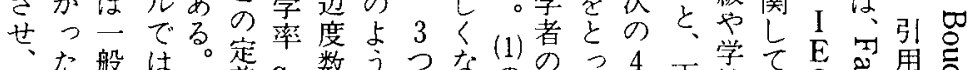

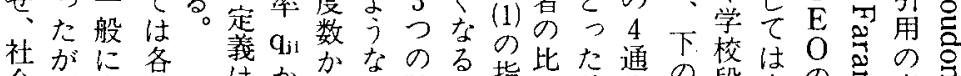

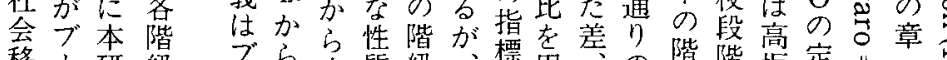

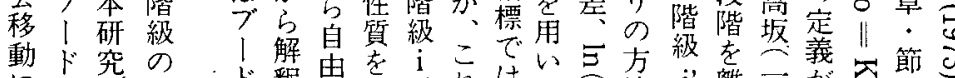

にン究の、ド釈由学

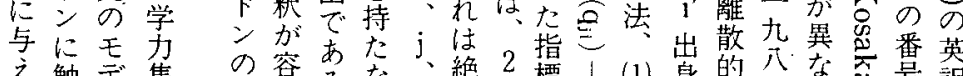

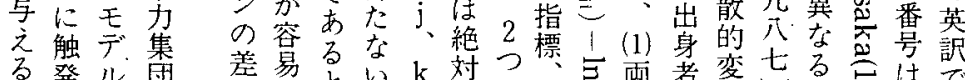

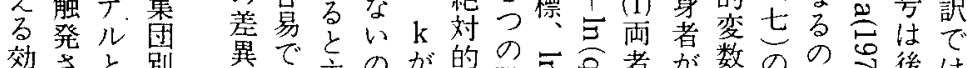

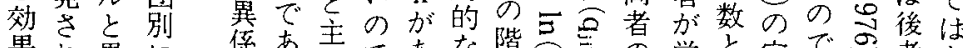

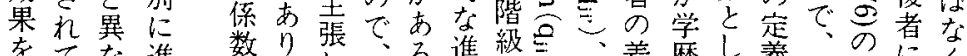

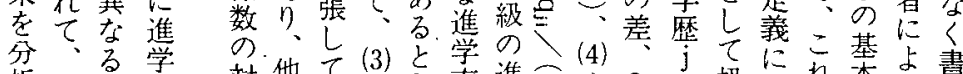

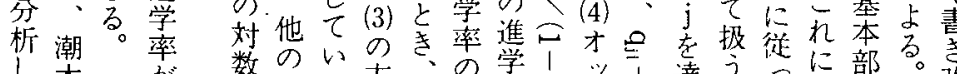

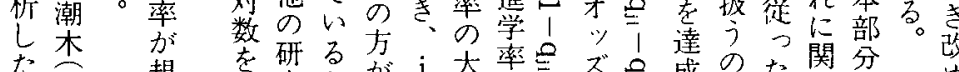

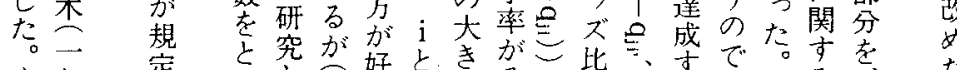

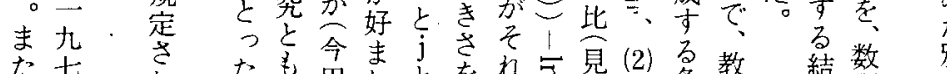

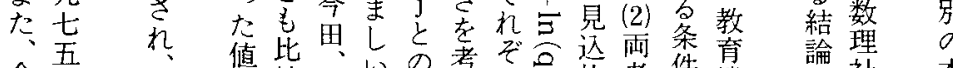

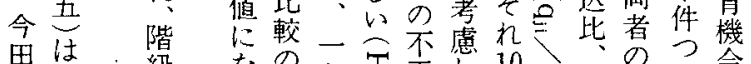

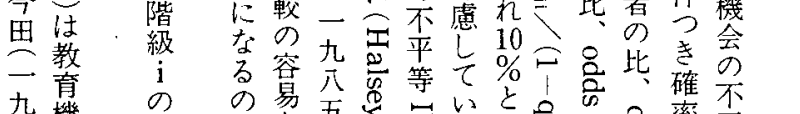

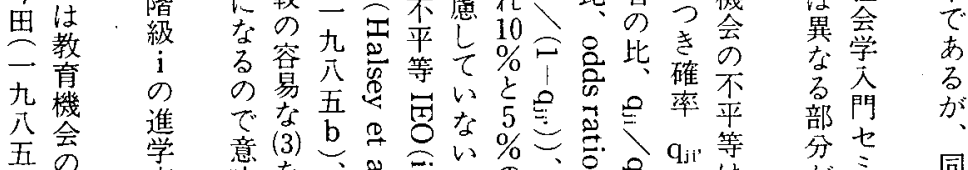

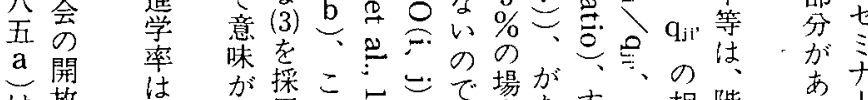

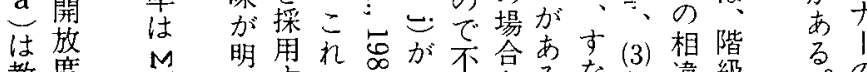

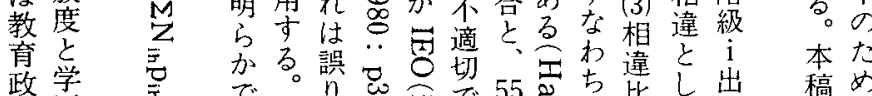

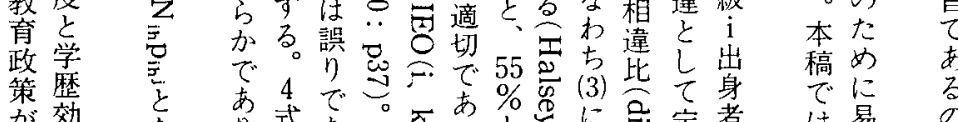

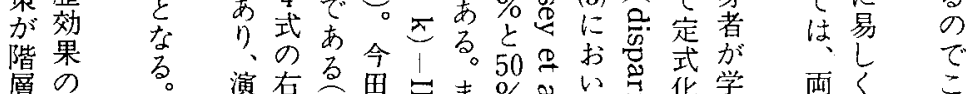

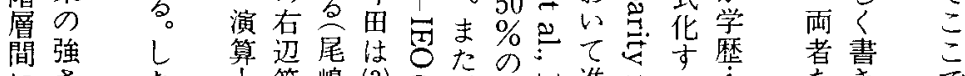

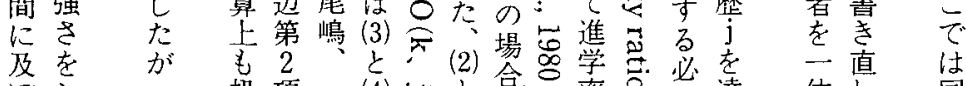

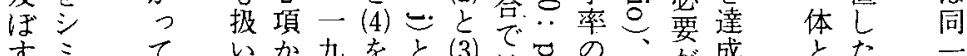

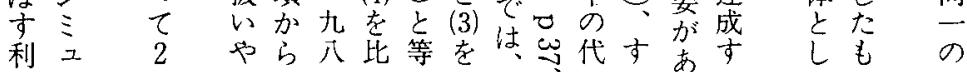

同
じ
論
旨
で
あ
る
で
こ
で
は
同
の 


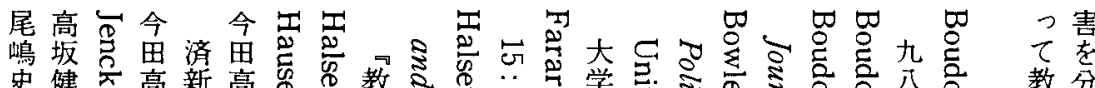

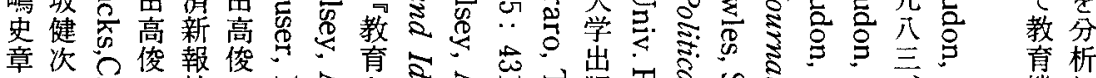

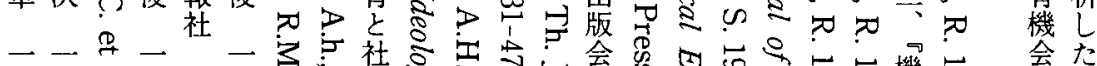

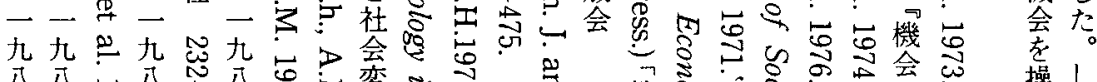

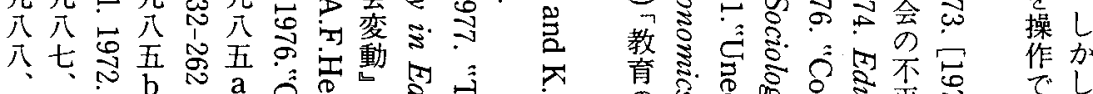

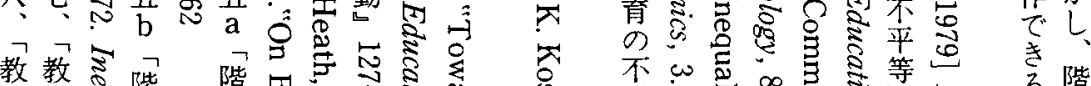

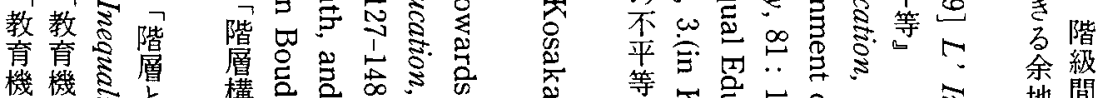

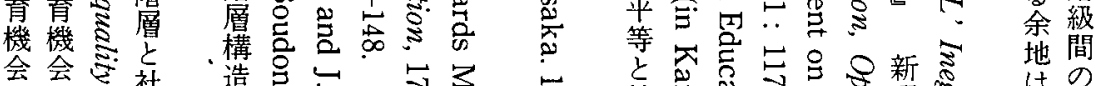

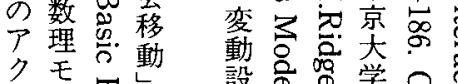

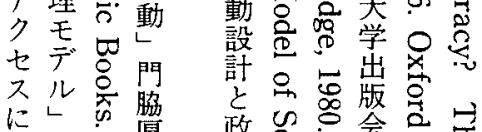

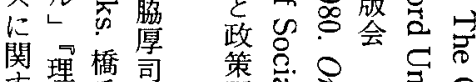

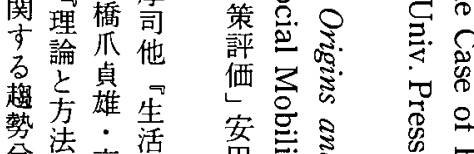

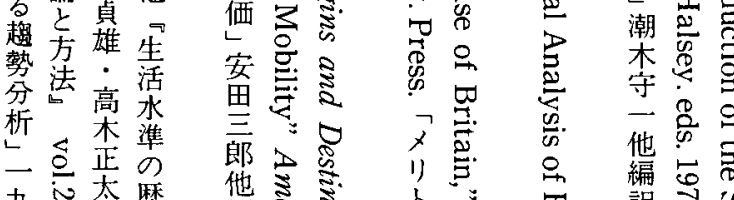

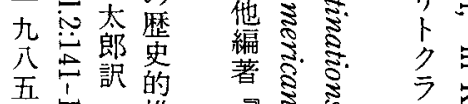

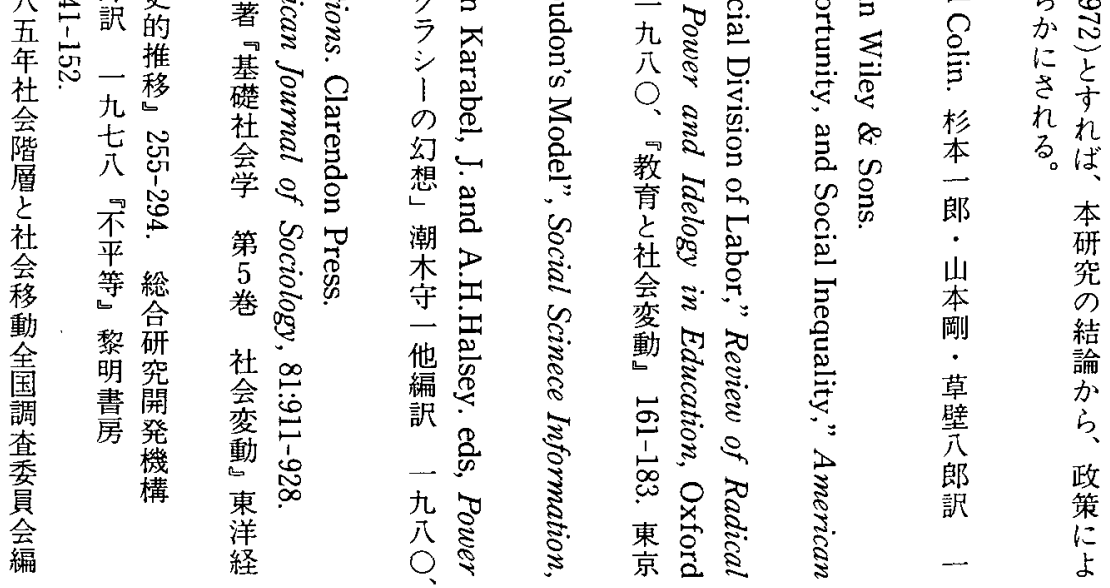




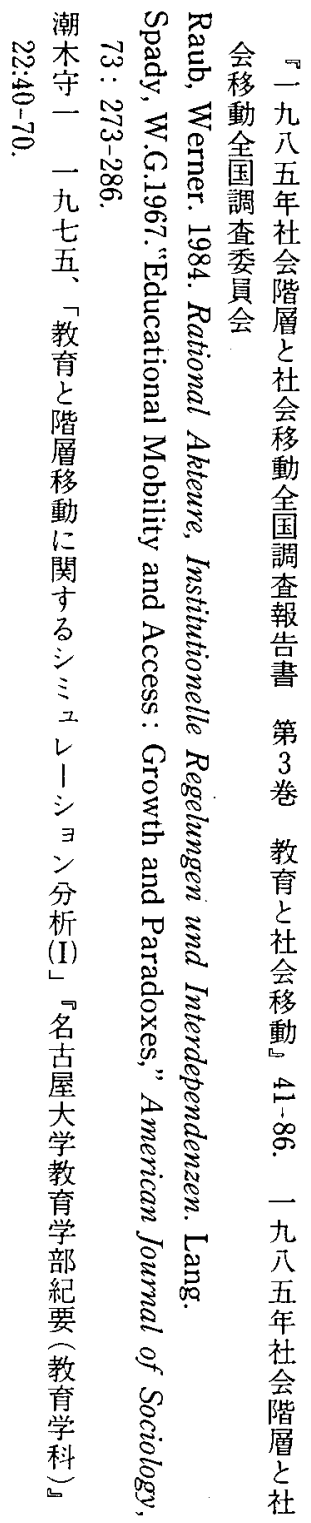




\title{
Inequality of Opportunity and Education
}

\author{
Takeyoshi Iwamoto \\ Kanazawa University
}

Education has two opposite functions - the channel of mobility and the media of inheritance. Although Boudon showed that enlargement of education bring smaller inequality of educational opportunity (IEO) using simulation, it contradicts empirical findings.

This article explored the cause of the failure of the simulation, and three factors which may maintain IEO are examined, using mathematical models. The models reviealed that enlargement of education can't vanish IEO and sometime bring larger IEO, if cultural difference between classes exists. Only in special case Boudon showed, IEO fall away perfectly. 